\title{
Serum Heart-Type Fatty Acid-Binding Protein and Cerebrospinal Fluid Tau: Marker Candidates for Dementia with Lewy Bodies
}

\author{
Brit Mollenhauer $^{\mathrm{a}, \mathrm{c}}$ Petra Steinacker ${ }^{\mathrm{c}}{ }^{\mathrm{f}}$ Erik Bahn ${ }^{\mathrm{d}}$ Mirko Bibl $^{\mathrm{e}}$ Peter Brechlin $^{\mathrm{c}}$ \\ Michael G. Schlossmacher ${ }^{\mathrm{a}}$ Joseph J. Locascio ${ }^{\mathrm{a}, \mathrm{b}}$ Jens Wiltfang ${ }^{\mathrm{g}}$ \\ Hans A. Kretzschmar ${ }^{\text {h }}$ Sigrid Poser ${ }^{c}$ Claudia Trenkwalder ${ }^{i}$ Markus Otto ${ }^{c, f}$ \\ ${ }^{a}$ Center for Neurologic Diseases, Brigham and Women's Hospital and b Memory and Movement Disorder Unit, \\ Massachusetts General Hospital, Harvard Medical School, Boston, Mass., USA; Departments of 'Neurology, \\ dPathology and ${ }^{e}$ Psychiatry, Georg August University, Göttingen, ${ }^{f}$ Department of Neurology, University of \\ Ulm, Ulm, ${ }^{9}$ Department of Psychiatry, Friedrich Alexander University, Erlangen/Nuremberg, ${ }^{\text {h}}$ Department of \\ Neuropathology, Ludwig Maximilians University Munich, Munich, and 'Georg August University Göttingen, \\ Paracelsus-Elena Klinik, Kassel, Germany
}

\section{Key Words}

Heart-type fatty acid-binding protein - Tau protein •

Alzheimer's disease - Dementia with Lewy bodies •

Parkinson disease dementia $\cdot$ Cerebrospinal fluid

\begin{abstract}
Background: The measurement of biomarkers in cerebrospinal fluid (CSF) has gained increasing acceptance in establishing the diagnosis of some neurodegenerative diseases. Heart-type fatty acid-binding protein (H-FABP) was recently discovered in CSF and serum of patients with neurodegenerative diseases. Objective: We investigated H-FABP in CSF and serum alone and in combination with CSF tau protein to
\end{abstract}

B.M. and P.S. contributed equally to this work. B.M. and M.O. were the principal investigators and together with P.S. designed, organized, and oversaw the trial and interpreted the data. C.T., M.B. and B.M. were responsible for all field- and hospital-based activities and diagnoses. M.G.S. was involved in the analysis and editing of the paper. J.J.L. was responsible for statistical analysis. H.A.K. and S.P. were involved in the CJD study. J.W., E.B. and P.B. were responsible for the quality control of the analyses.

\section{KARGER}

Fax +41613061234

E-Mail karger@karger.ch

www.karger.com
(C) 2007 S. Karger AG, Basel

$1660-2854 / 07 / 0045-0366 \$ 23.50 / 0$

Accessible online at:

www.karger.com/ndd evaluate these as potential biomarkers for the differentiation between dementia with Lewy bodies (DLB) and Alzheimer's disease (AD). Methods: We established H-FABP and tau protein values in a set of 144 persons with DLB $(n=33)$, Parkinson disease with dementia (PDD; $n=25), A D(n=35)$ and nondemented neurological controls (NNC; $n=51$ ). Additionally, serum H-FABP levels were analyzed in idiopathic Parkinson disease patients without evidence of cognitive decline $(n=45)$ using commercially available enzyme-linked immunosorbent assays. We calculated absolute values of $\mathrm{H}$ FABP and tau protein in CSF and serum and established relative ratios between the two to obtain the best possible match for the clinical working diagnosis. Results: Serum $\mathrm{H}$ FABP levels were elevated in DLB and PDD patients compared with NNC and AD subjects. To better discriminate between $D L B$ and $A D$, we calculated the ratio of serum H-FABP to CSF tau protein levels. At the arbitrary chosen cutoff ratio $\geq 8$ this quotient reached a sensitivity of $91 \%$ and a specificity of $66 \%$. Conclusion: Our results suggest that the measurement of CSF tau protein, together with $\mathrm{H}-\mathrm{FABP}$ quantification in serum and CSF, and the ratio of serum $\mathrm{H}$-FABP to CSF tau protein represent marker candidates for the differentiation between $A D$ and DLB.

Copyright $\odot 2007$ S. Karger AG, Base

Brit Mollenhauer

Center for Neurologic Diseases, Department of Neurology

Brigham and Women's Hospital, 77, Avenue Louis Pasteur

Harvard Institutes of Medicine (HIM) 764, Boston, MA 02115 (USA)

Tel. +1 617525 5123, Fax +1 617525 5252, E-Mail bmollenhauer@rics.bwh.harvard.edu 


\section{Introduction}

The distinction between dementia with Lewy bodies (DLB) and Alzheimer's disease (AD) remains challenging due to the significant overlap in clinical signs [1]. Today a definite diagnosis of the underlying neurodegenerative syndrome still requires neuropathological confirmation [2-4]. Early and accurate diagnosis becomes more and more important, since novel and disease-specific intervention trials are being planned, since unnecessary medication and tests are to be avoided, and since the costs for dementia care soar [5]. Biological markers supporting the clinical working diagnosis are often missing or do not meet requirements for routine standardization $[6,7]$.

So far the differentiation between AD and DLB based on the quantification of select constituents in cerebrospinal fluid (CSF) as potential surrogate markers, including of tau protein and $\beta$-amyloid $1-42$, has shown unsatisfactory results owing to the large overlap in values between the two syndromes [8-10]. Nonetheless, total tau protein may contribute to the clinical distinction between the tauopathy of AD and the synucleinopathy of DLB $[8,9]$.

Recently, heart-type fatty acid-binding protein $(\mathrm{H}$ FABP) was identified as a potential CSF biomarker for Creutzfeldt-Jakob disease (CJD) [11]. Fatty acid-binding proteins (FABPs) are cytosolic $14-$ to $16-\mathrm{kDa}$ proteins involved in the uptake, transport and metabolism of fatty acids. FABPs are found in all cells that utilize fatty acids, and are known to be rapidly released into the extracellular space following cellular damage. H-FABP was initially purified from heart muscle and previously evaluated as a biochemical marker of cardiac ischemia and brain injury [1214]. H-FABP has been found to display a wide tissue distribution including the expression in brain [15]. Another FABP is $\alpha$-synuclein, which is genetically and neuropathologically linked to Parkinson disease (PD) and DLB [16], and was recently shown to function as a FABP-like constituent of neurons, and to affect lipid metabolism in vivo [15-21]. $\alpha$-Synuclein-positive Lewy bodies request a pathological hallmark of DLB and PD, and are also found in sympathetic neurons of the peripheral nervous system including that of heart [22]. Based on these findings, myocardial scintigraphy using $\left.{ }^{[123} \mathrm{I}\right]$ metaiodobenzyl guanine has been investigated to help differentiate between synucleinopathies and tauopathies $[23,24]$.

In an independent pilot study of several degenerative dementias, high levels of CSF H-FABP were found in sporadic CJD patients and the highest number of $\mathrm{H}$-FABP reactivity was observed in the serum of a small cohort of DLB patients [25].
Accordingly, we carried out a cross-sectional study of $\mathrm{H}-\mathrm{FABP}$ and tau protein levels in biological fluids of a cohort of patients with neurodegenerative diseases to evaluate their individual diagnostic value individually and to explore combinatorial ratios thereof for the possible distinction between AD and DLB.

We hypothesized that H-FABP is a biomarker candidate not only for DLB but also possibly for Parkinson disease with dementia (PDD) given their virtually identical phenotype of central nervous system pathology. The biochemical parallels between $\alpha$-synuclein and H-FABP as well as several links between tau protein, $\alpha$-synuclein and parkinsonism provided further impetus for our study [19-21]. Here, we demonstrate that H-FABP together with CSF tau protein has the potential to be of use in the differential diagnosis of several neurodegenerative diseases, especially the distinction between DLB and AD.

\section{Methods}

\section{Patients}

We analyzed CSF and serum of 144 patients with DLB, PDD, $\mathrm{AD}$ and nondemented neurological controls (NNC). Additionally, we examined serum of 45 patients with idiopathic Parkinson disease without dementia (IPD). All samples were drawn in the morning under fasting conditions. Routine laboratory investigations (e.g. liver enzymes, creatinine, creatine phosphokinase, lactate dehydrogenase, total protein content in serum as well as complete cell count and protein level in the CSF) were normal, and no patient showed signs of acute myocardial infarction (clinically or by laboratory investigations and electrocardiogram) or of overt congestive heart failure. In all patients either computed tomography or magnetic resonance imaging of the brain was carried out to exclude structural entities.

None of the patients included received medication known to potentially affect the lipid metabolism. In the case of evidence for another cause of dementia (e.g. recent or acute cardiac or cerebral infarction) subjects were excluded.

\section{Dementia with Lewy Bodies}

Patients diagnosed as 'probable DLB' at a neurological university hospital (according to the clinical classification criteria of McKeith et al. [2, 3]) were hospitalized for $\geq 24 \mathrm{~h}$ to evaluate them for fluctuating cognition, extrapyramidal symptoms and visual hallucinations. All DLB patients developed dementia before extrapyramidal symptoms and were thus differentiated from PDD according to DLB guidelines $[2,3]$. We included 10 male and 23 female DLB patients with a mean age of $70 \pm 9$ years $( \pm S D$; range 66-86 years) (table 1). Disease duration at the time of lumbar puncture (LP) was $24 \pm 21$ months (range: 6-72 months). Mean MMSE was $14 \pm 5$ points (range: 9 and 21 points; normal: 30 ).

\section{$P D D$ and IPD}

All PD patients were evaluated and their course followed in a specialized clinic for parkinsonism and movement disorders (Paracelsus-Elena Klinik, Kassel, Germany). The diagnosis was 
Table 1. Demographics and phenotypic characterization of study participants

\begin{tabular}{|c|c|c|c|c|c|}
\hline & $\begin{array}{l}\text { DLB } \\
(n=33)\end{array}$ & $\begin{array}{l}\text { PDD } \\
(n=25)\end{array}$ & $\begin{array}{l}\mathrm{AD} \\
(\mathrm{n}=35)\end{array}$ & $\begin{array}{l}\text { IPD } \\
(n=45)\end{array}$ & $\begin{array}{l}\text { NNC } \\
(n=51)\end{array}$ \\
\hline Age, years & $70 \pm 9$ & $74 \pm 6$ & $68 \pm 11$ & $69 \pm 10$ & $67 \pm 12$ \\
\hline Range & $66-86$ & $56-84$ & $63-85$ & $45-84$ & $32-94$ \\
\hline Median & 72 & 74 & 65 & 68 & 66 \\
\hline Sex (male/total) & 0.3 & 0.8 & 0.4 & 0.6 & 0.4 \\
\hline Duration of disease & $24 \pm 21$ months & $156 \pm 72$ months & $44 \pm 25$ months & $132 \pm 96$ months & n.a. \\
\hline Range & $6-72$ months & $48-336$ months & $8-84$ months & $24-444$ months & \\
\hline Median & 14 months & 132 months & 40 months & 120 months & \\
\hline MMSE & $14 \pm 5$ & $18 \pm 7$ & $16 \pm 6$ & $>28$ & 30 \\
\hline Range & $9-21$ & $5-25$ & $3-24$ & & \\
\hline Median & 14 & 11 & 40 & & \\
\hline UPDRS & n.a. & $49 \pm 13$ & n.a. & $40 \pm 18$ & n.a. \\
\hline Range & & $30-83$ & & $10-69$ & \\
\hline Median & & 48 & & 46 & \\
\hline Hoehn and Yahr & n.a. & $4 \pm 1$ & n.a. & $3.5 \pm 1$ & n.a. \\
\hline Range & & $2-5$ & & $1-5$ & \\
\hline Median & & 4 & & 3.75 & \\
\hline
\end{tabular}

MMSE = Mini-Mental Status Examination; n.a. = not available.

made according to the UK Brain Bank diagnostic criteria for clinically definite PD [26]. All PD patients had suffered from idiopathic PD for at least 3 years prior to the occurrence of cognitive decline (in PDD cases) or showed no change in cognition (IPD).

The Hoehn and Yahr (H\&Y) score was used for classification of clinical disability [27]. All PD patients were also evaluated using the motor subscale of the Unified Parkinson Disease Rating Scale (UPDRS part III, items 18-31) during their on-state [28]. They all received treatment according to widely used practice guidelines $[29,30]$.

PD patients were divided into two groups:

(1) IPD patients: This group comprised 45 patients. All IPD patients had an MMSE $>28$ points and showed no signs of psychosis or depression.

We included 45 patients (17 males and 28 females) with IPD of whom blood samples were available for H-FABP quantification (table 1). No CSF samples were available from these IPD patients. Mean age in this group was $69 \pm 10$ years (range: $45-84$ years). The duration of IPD was $231 \pm 96$ months and ranged between 24 and 444 months; classification according to $H \& Y$ was $3.5 \pm 1$ and ranged between 1 and 5, and the mean UPDRS score was 40 \pm 18 and ranged between 10 and 69 .

(2) PDD patients: This group comprised 25 patients. All PDD fulfilled the DSM-IV criteria for dementia and presented with an MMSE $\leq 25$ points, thereby defining dementia. All patients were examined by a neurologist and either by a psychologist and/or psychiatrist to exclude the diagnosis of depression. Subjects with MMSE $\geq 25$ were excluded as were those with signs of depression.

We included 20 male and 5 female PDD patients with a mean age of $74 \pm 6$ years (range: $56-84$ years) (table 1 ). Mean duration of PDD at the time of LP was $156 \pm 72$ months (range: $48-336$ months). Mean MMSE was $18 \pm 7$ points (range: $5-25$ points). H\&Y classification was $4 \pm 1$ and ranged between 2 and 4 ; mean UPDRS (part III) was $49 \pm 13$ and ranged between 30 and 83 .

\section{Alzheimer's Disease}

We included patients with the diagnosis of AD recruited in the departments of psychiatry and neurology. The diagnosis of 'probable AD' in all 34 cases was made according the DSM-IV criteria for dementia and the established NINCDS-ADRDA criteria [31]. For 1 patient, neuropathological verification of $A D$ was obtained postmortem using paraffin-embedded formalin fixation of brain tissue and immunohistochemistry.

We included 15 male and 20 female patients with AD (table 1). Their mean age was $68 \pm 11$ years and ranged between 63 and 85 years. MMSE was $16 \pm 6$ points (range: $3-24$ points). Disease duration was $44 \pm 25$ months (range: $8-84$ months).

\section{Nondemented Neurological Controls}

NNC patients underwent LP during routine workup of nondementing illnesses. These patients suffered from the following clinical working diagnoses: headache $(n=12)$, peripheral neurological diseases $(n=10)$, depression $(n=8)$, focal cerebral ischemia $(n=5)$, epileptic seizures $(n=3)$, amyotrophic lateral sclerosis $(n=2)$, dizziness $(n=2)$, myelopathy or radiculopathy $(n=6)$, and multiple sclerosis, small cell lung carcinoma without metastasis to the central nervous system, and transient global amnesia $(n=3)$.

Patients with cognitive changes and/or extrapyramidal signs were excluded from our study. There were 20 male and 31 female patients In the NNC group with a mean age of $67 \pm 12$ years (range: 32-94 years) (table 1).

\section{Marker Measurement}

Tau Protein

All specimens were obtained by LP, aliquoted and stored at $-80^{\circ} \mathrm{C}$. All samples were analyzed using a commercially available enzyme-linked immunosorbent assay for tau protein (INNOTEST hTAU Antigen, Innogenetics, Gent, Belgium) [32-34]. 
Table 2. Laboratory data according to working diagnosis

\begin{tabular}{lccccc}
\hline & DLB & PDD & AD & IPD & NNC \\
\hline Tau protein in CSF, pg/ml & $285 \pm 196$ & $248 \pm 141$ & $945 \pm 1,821$ & n.a. & $150 \pm 109$ \\
$\quad$ Range & $75-973$ & $99-702$ & $75-11,152$ & & $75-583$ \\
$\quad$ Median & 220 & 192 & 691 & & 116 \\
H-FABP in CSF, pg/ml & $1,511 \pm 843$ & $1,278 \pm 1,207$ & $1,607 \pm 950$ & n.a. & $861 \pm 506$ \\
$\quad$ Range & $341-3,476$ & $100-6,400$ & $399-4,980$ & & $100-2,507$ \\
Median & 1,283 & 1,283 & 1,542 & & 800 \\
H-FABP in serum, pg/ml & $10,199 \pm 15,526$ & $6,699 \pm 9,271$ & $3,299 \pm 2,090$ & $2,714 \pm 2,406$ & $3,734 \pm 6,824$ \\
$\quad$ Range & $510-89,688$ & $1,824-40,675$ & $581-9,029$ & $288-11,021$ & $361-35,683$ \\
$\quad$ Median & 7,337 & 3,121 & 3,055 & 2,250 & 1,983 \\
\hline
\end{tabular}

n.a. $=$ Not available

The signal corresponding to the lowest values for tau protein was equalized to the lowest standard concentration at $75 \mathrm{pg} / \mathrm{ml}$.

\section{$\mathrm{H}-\mathrm{FABP}$ in CSF and Serum}

$\mathrm{H}$-FABP levels were measured in $25-\mu \mathrm{l}$ aliquots of serum and $50-\mu \mathrm{l}$ aliquots of CSF, using a commercially available solid-phase enzyme-linked immunoassay based on the sandwich principle (HyCult Biotechnology, The Netherlands). Specificity of the antibodies to H-FABP was previously established by Pelsers et al. [35], as cross-reactivity with non-H-FABP had been excluded. No performance differences were observed in the FABP assay when applying serum or plasma; samples subjected to freeze and thaw cycles showed no loss of immunoreactivity [36]. Signals corresponding to the lowest values of $\mathrm{H}$-FABP reactivity were set at the lowest standard concentration of $200 \mathrm{pg} / \mathrm{ml}$ of recombinant protein.

The study was approved by the Ethics Committee of the University of Göttingen and the local board of registration of Hessen, Germany. Investigations were carried out with the informed consent of all patients or their next of kin in the case of persons with dementia.

\section{Statistical Analysis}

Statistical analysis was performed applying the Mann-Whitney test, when values from two cohorts were compared. For more than two groups the Kruskal-Wallis test was applied. To illustrate the variability of sensitivity and specificity for different cutofflevels of the different marker combinations the receiver-operating characteristic (ROC) curve was computed. In addition, the area under the curve (AUC) for ROC curves was calculated. There, higher levels represented a better test performance [37]. Only the best discriminating cutoff values alone or in combination are presented. Spearman correlations are given with $\mathrm{p}$ value and correlations $(\mathrm{c})$.

To confirm results from our exploratory statistical approach, we conducted linear discriminant and logistic regression analyses. This statistical approach was carried out by an experienced statistician (J.J.L.) using SAS. Logarithmic transformations of values $(\log )$ were used to meet assumptions of normality and homogeneity of variances for some of the statistical tests.

\section{Results}

\section{Tau Protein Levels in CSF}

In diseased brains the mean CSF tau protein was 285 $\pm 196 \mathrm{pg} / \mathrm{ml}$ (range: $75-973 \mathrm{pg} / \mathrm{ml}$ ) for DLB, $248 \pm 141$ $\mathrm{pg} / \mathrm{ml}$ (range: $99-702 \mathrm{pg} / \mathrm{ml}$ ) in PDD and $949 \pm 1,821$ $\mathrm{pg} / \mathrm{ml}$ (range: $75-11,152 \mathrm{pg} / \mathrm{ml}$ ) in AD. Tau protein levels were $150 \pm 109 \mathrm{pg} / \mathrm{ml}$ (range: $75-583 \mathrm{pg} / \mathrm{ml}$ ) in the control group (NNC) (table 2, fig. 1).

Mean tau protein levels were significantly different between the cohorts of AD and DLB and AD and PDD ( $<<$ $0.001)$ as well as between both DLB and AD and NNC $(p<0.001)$ as reported [9]. At a reduced level of statistical significance, tau protein levels differed between PDD and NNC ( $p=0.01)$. No difference was seen between PDD and DLB ( $p=0.18)$ as expected, as they share nearly identical neuropathological phenotypes $[38,39]$.

Total CSF tau protein was the most useful discriminating parameter at the best fit cutoff of $240 \mathrm{pg} / \mathrm{ml}$ between AD and NNC, with a sensitivity of $86 \%$ and a specificity of $92 \%$.

The patient with neuropathologically verified $\mathrm{AD}$ in our cohort had undergone LP 2 months after the onset of disease (4 years prior to death), and his CSF tau level was $1,126 \mathrm{pg} / \mathrm{ml}$.

\section{H-FABP Levels in CSF}

To further discriminate between PDD, DLB and AD, we next examined CSF H-FABP levels (tables 2, fig. 1). In DLB, H-FABP was $1,511 \pm 843 \mathrm{pg} / \mathrm{ml}$ (range: $341-3,476$ $\mathrm{pg} / \mathrm{ml}$ ), in PDD $1,278 \pm 1,207 \mathrm{pg} / \mathrm{ml}$ (range: $100-6,400$ $\mathrm{pg} / \mathrm{ml}$ ) and in $\mathrm{AD} 1,607 \pm 950 \mathrm{pg} / \mathrm{ml}$ (range: 399-4,980 $\mathrm{pg} / \mathrm{ml})$. In the NNC group, CSF H-FABP levels were 861 $\pm 506 \mathrm{pg} / \mathrm{ml}$ (range: $100-2,507 \mathrm{pg} / \mathrm{ml}$ ). 
Fig. 1. Logarithmic box plot of CSF tau protein and H-FABP in serum and CSF in DLB, PDD, AD and NNC.

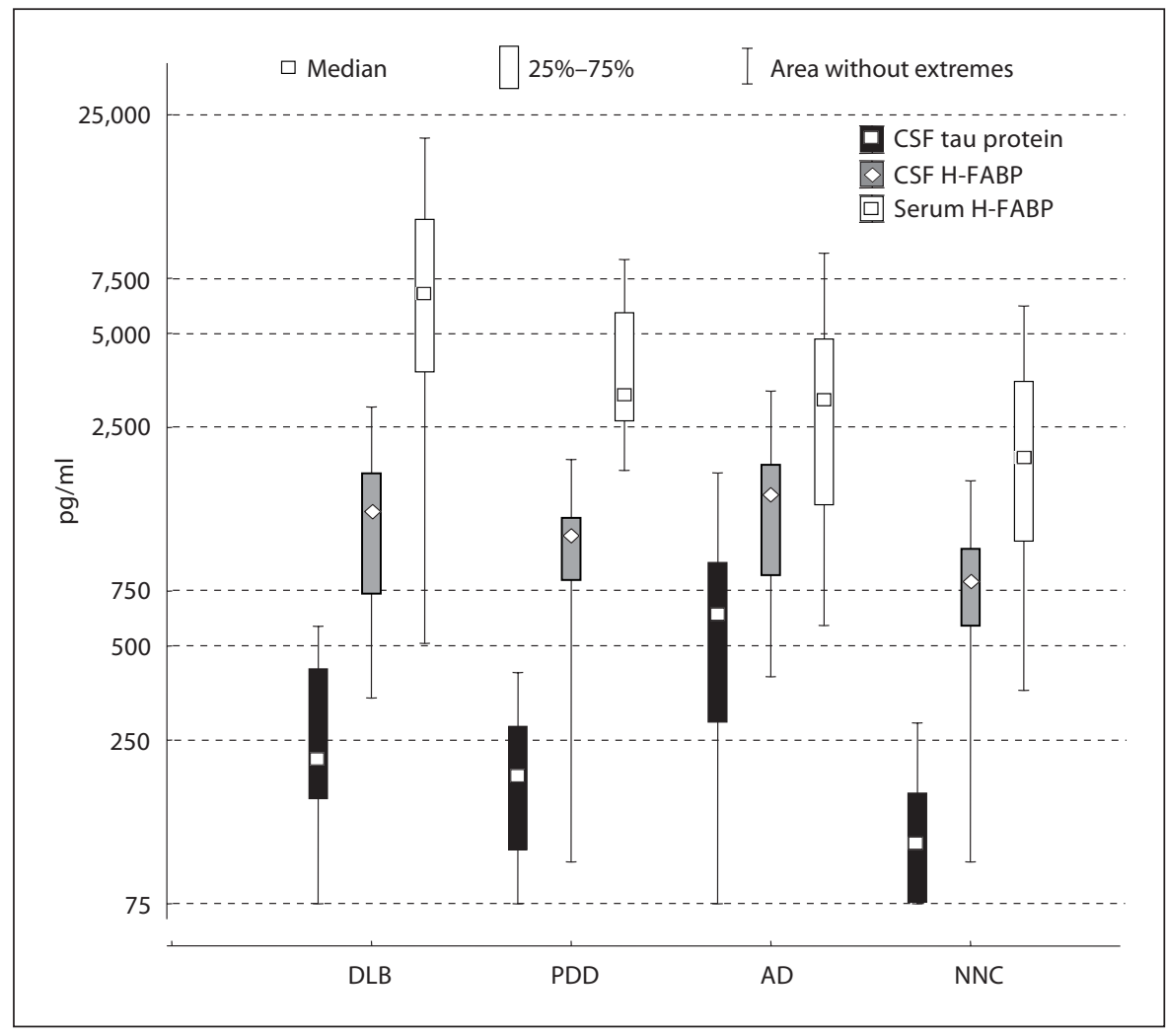

Accordingly, H-FABP levels were highly significantly different between DLB as well as AD and NNC ( $\mathrm{p}<$ $0.001)$. Statistical significance was also observed between PDD and NNC $(\mathrm{p}=0.03)$, but did not differ between AD and DLB ( $\mathrm{p}=0.64)$, PDD and DLB $(\mathrm{p}=0.16)$, and PDD and $\mathrm{AD}(\mathrm{p}=0.08)$.

\section{H-FABP Levels in Serum}

To pursue a higher order of diagnostic accuracy, we next determined serum H-FABP levels in our subjects. These were higher (mean: 10,199 $\pm 15,526 \mathrm{pg} / \mathrm{ml}$ ) and ranged between 510 and $89,688 \mathrm{pg} / \mathrm{ml}$ in DLB. In PDD, the mean serum H-FABP levels were 6,699 $\pm 9,271 \mathrm{pg} / \mathrm{ml}$ (range: $1,824-40,675 \mathrm{pg} / \mathrm{ml}$ ) and in AD cases 3,299 \pm $2,090 \mathrm{pg} / \mathrm{ml}$ (range: $581-9,029 \mathrm{pg} / \mathrm{ml}$ ). The NNC showed mean serum H-FABP levels of $3,734 \pm 6,824 \mathrm{pg} / \mathrm{ml}$ (range: $361-35,683 \mathrm{pg} / \mathrm{ml}$ ) (table 2, fig. 1, 2). Thus, serum levels of H-FABP significantly differed between DLB and AD $(p<0.001)$ and between both PDD and DLB over NNC $(\mathrm{p}<0.001)$.

The one patient with neuropathological verification of the clinical diagnosis of AD showed a serum H-FABP of $5,923 \mathrm{pg} / \mathrm{ml}$ and a CSF H-FABP level of 2,419 pg/ml.
Suspected Synucleinopathies

To further examine cohorts of clinically suspected synucleinopathies, we also investigated a group of IPD patients. Mean serum H-FABP levels were 2,714 $\pm 2,406$ $\mathrm{pg} / \mathrm{ml}$ (range: $288-11,021 \mathrm{pg} / \mathrm{ml}$ ) (table 2, fig. 2).

Intriguingly, serum $\mathrm{H}-\mathrm{FABP}$ levels were significantly different between PDD and DLB versus IPD $(\mathrm{p}<0.001)$; however, no difference was seen between PDD and DLB $(p=0.14)$ as expected. Thus, in our cohort analyses, serum H-FABP alone could discriminate between parkinsonism with dementia versus classical PD without cognitive impairment (e.g. PDD and DLB vs. IPD) (fig. 2). Best cutoff points regarding the AUC varied among the clinical working diagnoses and reached sensitivities between 69 and $92 \%$, and specificities between 64 and $88 \%$ (table 3).

\section{Combinational Analysis}

To achieve a higher degree of specificity and sensitivity, and possibly allow a laboratory value-based distinction between our various cohorts, we next examined the usefulness of various combined test values.

Ratios of H-FABP serum to CSF levels showed significant differences between both the PDD and DLB groups 
Fig. 2. Box plot of H-FABP in serum in IPD, PDD, DLB, NNC and AD.

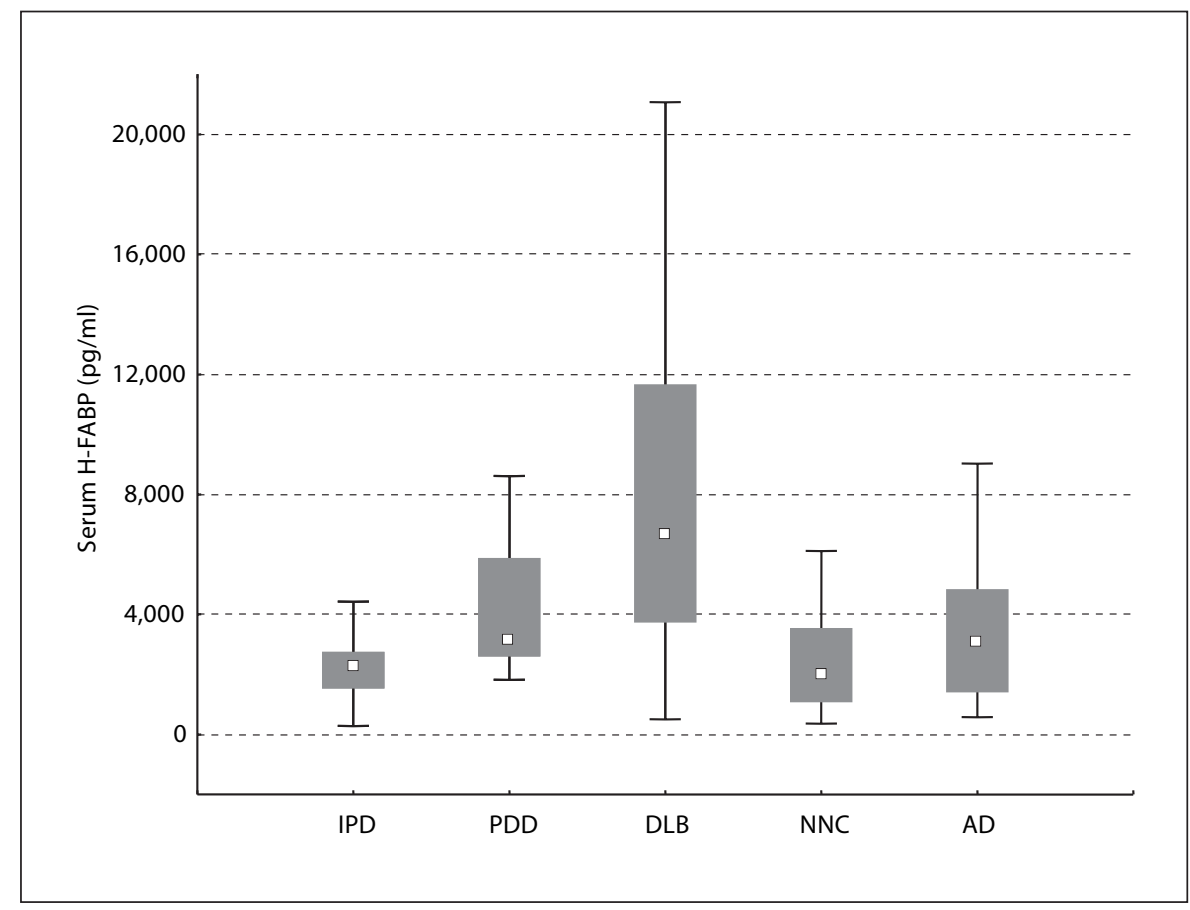

Table 3. Overview of the most informative parameters and chosen cutoff levels in correlation with working diagnosis

\begin{tabular}{|c|c|c|c|c|c|}
\hline $\begin{array}{l}\text { Working } \\
\text { diagnosis }\end{array}$ & Most informative parameter & Best cutoff & $\begin{array}{l}\text { Sensitivity } \\
\%\end{array}$ & $\begin{array}{l}\text { Specificity } \\
\%\end{array}$ & $\mathrm{AUC}^{\mathrm{a}}$ \\
\hline \multirow[t]{3}{*}{ DLB vs. AD } & serum H-FABP & $>4,000 \mathrm{pg} / \mathrm{ml}$ & 71 & 69 & $0.799 *$ \\
\hline & serum H-FABP/CSF H-FABP & $>3.3$ & 80 & 74 & $0.779^{*}$ \\
\hline & serum $\mathrm{H}-\mathrm{FABP} / \mathrm{CSF}$ tau protein & $>8.0$ & 91 & 66 & $0.866^{*}$ \\
\hline DLB vs. PDD & serum $\mathrm{H}-\mathrm{FABP}$ & $>3,500 \mathrm{pg} / \mathrm{ml}$ & 81 & 65 & 0.693 \\
\hline DLB vs. IPD & serum H-FABP & $>3,200 \mathrm{pg} / \mathrm{ml}$ & 84 & 82 & $0.836^{*}$ \\
\hline DLB vs. NNC & serum H-FABP & $>4,500 \mathrm{pg} / \mathrm{ml}$ & 74 & 88 & $0.819^{*}$ \\
\hline PDD vs. AD & serum $\mathrm{H}-\mathrm{FABP} / \mathrm{CSF}$ tau protein & $>9.0$ & 88 & 74 & $0.840^{*}$ \\
\hline PDD vs. IPD & serum $\mathrm{H}-\mathrm{FABP} \mathrm{P}^{\mathrm{b}}$ & $>2,800 \mathrm{pg} / \mathrm{ml}$ & 69 & 80 & $0.783^{*}$ \\
\hline PDD vs. NNC & serum H-FABP & $>2,350 \mathrm{pg} / \mathrm{ml}$ & 92 & 64 & $0.750^{*}$ \\
\hline AD vs. NNC & CSF tau protein & $>240 \mathrm{pg} / \mathrm{ml}^{\mathrm{c}}$ & 86 & 92 & $0.925^{*}$ \\
\hline 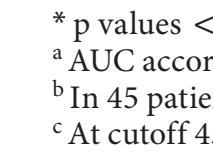 & $\begin{array}{l}01 . \\
\text { to the ROC curves }[36] \text {. } \\
\text { with IPD only serum was analyz } \\
g / \mathrm{ml}[32,33] \text { sensitivity was } 60 \%\end{array}$ & . c. & & & \\
\hline
\end{tabular}

versus $\mathrm{AD}$ ( $\mathrm{p}=0.003$ and $\mathrm{p}<0.001$, respectively) (table 3, fig. 3). Accordingly, the ratio of serum H-FABP to CSF tau showed highly significant differences between AD and DLB and successfully discriminated between both diseases at the chosen best-fit cutoff of $\geq 8.0$, with a sensitivity of $91 \%$ and a specificity of $66 \%$ (table 3 , fig. 4). At a chosen cutoff of $\geq 9$, this quotient discriminated between AD and PDD with a sensitivity of $88 \%$ and a specificity of $74 \%$ (table 3 , fig. 3).

Consistent with these results, logistic regression analyses of individual and combinations of marker variables showed significant $(\mathrm{p}<0.001)$ and optimal separation of 
DLB and AD with a linear combination of log CSF tau (coefficient $=-1.58)$ and log serum H-FABP (1.35), each marker providing significant $(\mathrm{p}=0.001)$ classification power beyond that of the other. This combination produced an AUC of 0.869 and reflected well the ratio between serum H-FABP and CSF tau protein with an AUC of 0.866 we introduced for practical reasons.

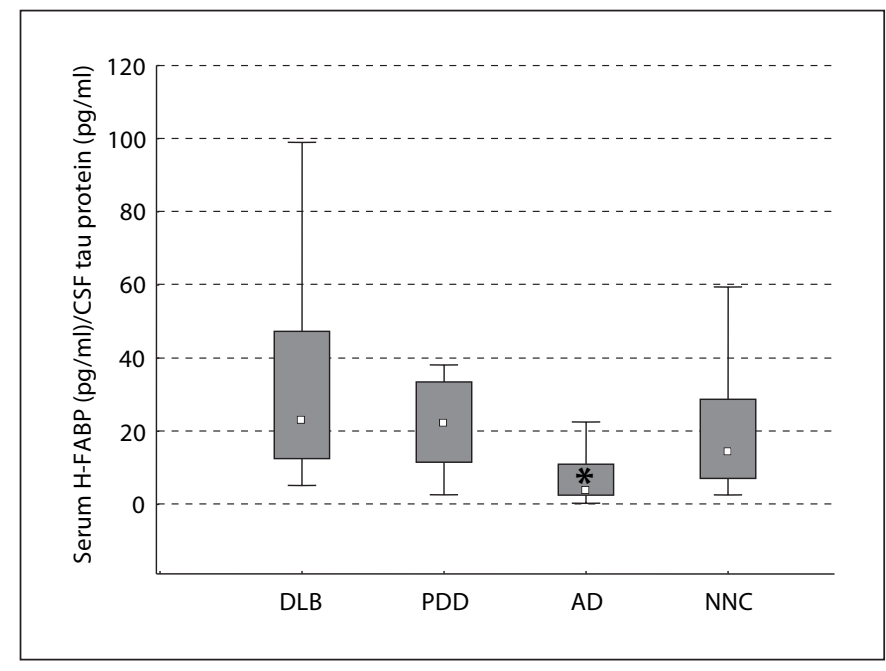

Fig. 3. Box plot of quotient serum $\mathrm{H}-\mathrm{FABP} / \mathrm{CSF}$ tau protein in DLB, PDD, AD and NNC. * Neuropathologically verified AD patient.

\section{Discussion}

We evaluated CSF tau protein together with H-FABP in CSF and serum in a larger group of patients suffering from neurodegenerative dementia, and compared these markers with NNC including subjects with idiopathic PD. Among the latter, we included subjects with and without dementia according to widely used clinical criteria (see Methods section). Tau protein is an accepted marker in the differential diagnosis of neurodegenerative diseases [40], whereas H-FABP was only recently described [11]. Giving the intriguing parallels between $\mathrm{H}$ FABP and $\alpha$-synuclein biology as well as the pathological links between $\alpha$-synuclein and tau protein [41], we analyzed both H-FABP and tau-protein for their best-differential diagnostic potential for discriminating between $\mathrm{DLB}$ and $\mathrm{AD}$ by evaluating practical cutoff levels and ratios.

Based on data with elevated CSF H-FABP and normal serum H-FABP values in $30 \mathrm{CJD}$ patients (data not shown), we concluded that $\mathrm{H}$-FABP proteins in CSF from CJD subjects are likely to originate from the brain and not from a peripheral source [25]. In contrast, the high levels of serum H-FABP in DLB and PDD compared to IPD, NNC and AD (without corresponding H-FABP elevation in CSF) suggested that H-FABP dysregulation
Fig. 4. ROC curves for the differential diagnosis of DLB versus AD using cutoff points and marker combinations. Best results (e.g. highest AUC) were obtained for the quotient of serum H-FABP/CSF tau protein.

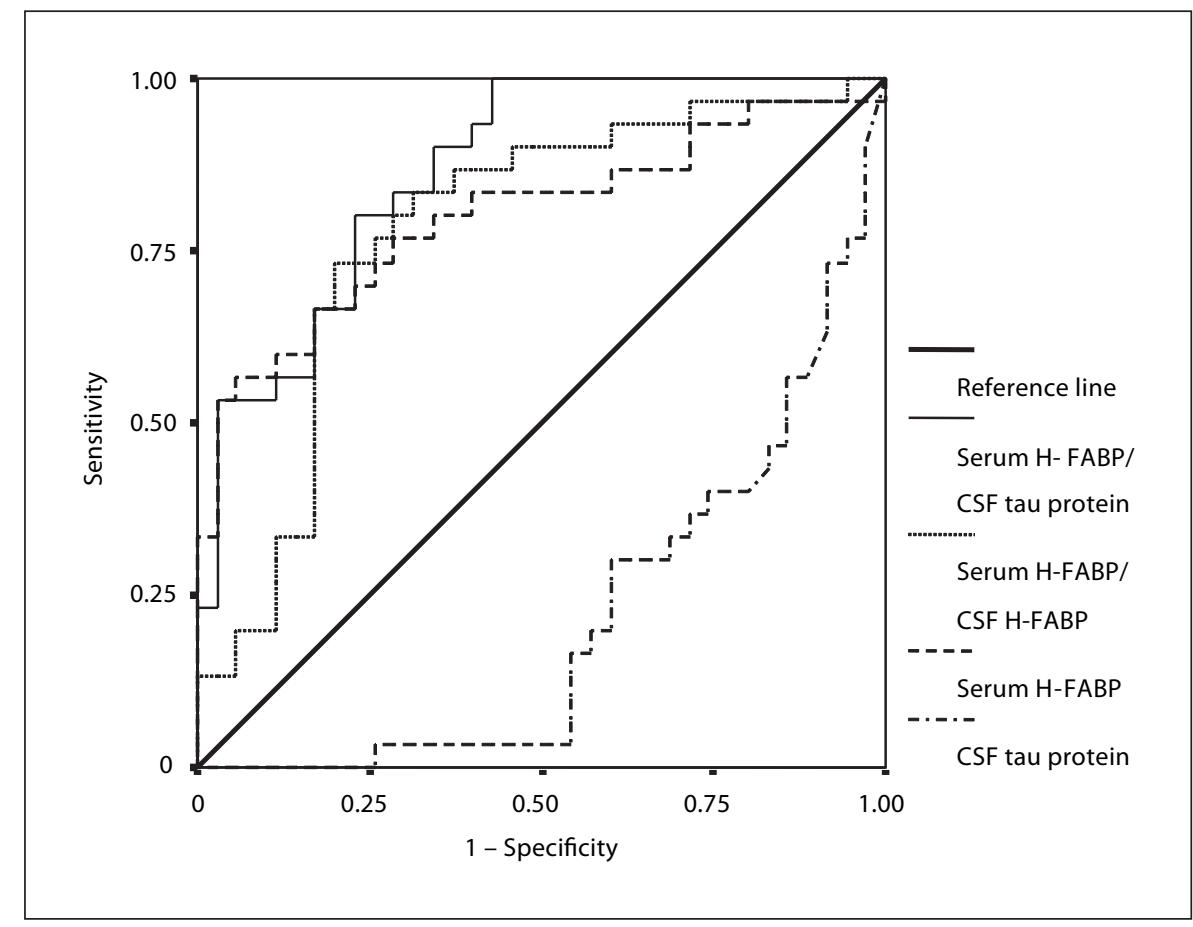


was more likely related to a peripheral rather than neural source.

In none of our patients, was clinically or laboratorybased cardiac dysfunction recognizable and no other organ dysfunction could be identified.

The generally held distinction between PDD and DLB rests on the observation that the disease begins with either motor or cognitive signs, respectively, and that progression is more rapid and more widespread in DLB than in PDD. Neuropathologically, there is no substantive qualitative difference in their $\alpha$-synucleinopathy phenotypes [39].

$\mathrm{H}-\mathrm{FABP}$ is a member of a protein family found in brain as well as in heart tissue (from where H-FABP was initially purified) [15]. Upon detection of release of $\mathrm{H}$ FABP from myocardial tissue following cellular damage, plasma H-FABP levels were explored as candidate marker for myocardial ischemia $[12,13,35]$. Elevated levels of brain-derived serum H-FABP were seen in patients following brain injury including cerebral ischemia and hemorrhage [42-44]. However, these acute disease entities are less relevant in the case of chronically evolving neurodegenerative disease, and are therefore unlikely to present a diagnostic dilemma in the neurological practice setting.

It is currently unknown whether elevated serum $\mathrm{H}$ FABP levels seen in DLB and PDD are the result of cardiac involvement in the disease process or of systemic upregulation. Of note, $\alpha$-synuclein-positive Lewy bodies are found in sympathetic neurons of the peripheral nervous system including the conduction system of the heart, and these are frequently found abnormal in DLB and PD [22, 23, 45]. These peripheral nervous system changes gave rise to the hypothesis of a peripheral starting point for the disease [38]. Importantly, future studies will further explore H-FABP levels in serum and CSF of synucleinopathy subjects, and will include the recently developed quantification of $\alpha$-synuclein by ELISA [46-48].

A primary or secondary role of H-FABP in the widespread synucleinopathies of PDD and DLB could underlie our observed laboratory changes, as $\alpha$-synuclein has fatty acid-binding capacities, and a reciprocal interaction between polyunsaturated fatty acids and $\alpha$-synuclein has recently been demonstrated in vivo [19-21]. Therefore, $\mathrm{H}$-FABP might be upregulated in concert with dysregulated $\alpha$-synuclein processing $[17,18,21]$. It was also shown that H-FABP is associated with the dompamine D2 receptor [49]. Future studies will address the systemic mRNA levels of H-FABP in our patient cohorts, and $\mathrm{H}$ -
FABP levels in cellular and animal models of synucleinopathies.

Aside from the important pathophysiological question, we have demonstrated a potential relevance of serum and CSF H-FABP levels for clinical practice. The best discriminator for the clinically often challenging distinction between DLB and PDD over AD in our study was the ratio of serum H-FABP to CSF tau, where a larger number suggested a higher probability of synucleinopathy in the clinical context of dementia (fig. 3). Such a degree of discrimination is not yet possible with currently investigated markers [8-10]. To date, CSF markers (such as tau protein alone and in combination with $\beta$ amyloid 1-42) fail to discriminate between AD and DLB because of a sizeable overlap and thus do not fulfil the requirements of a reliable biomarker [7]. Future examination of additional cohorts may support the clinical separation of AD from DLB (and PDD subjects) using serum $\mathrm{H}-\mathrm{FABP} / \mathrm{CSF}$ tau ratios.

We are aware of several potential weaknesses of our study: (1) its cross-sectional design and (2) the partial overlap seen between PDD and DLB groups versus our NNC cohort (fig. 3). We will seek to address these in a prospective study with phenotypically well-characterized cohorts and include the quantification of CSF and blood $\alpha$-synuclein levels [46-48]. In contrast to other ongoing biomarker development efforts (e.g. functional and structural neuroimaging studies), our CSF and serumbased assays for tau and H-FABP reactivities carry with them the potential benefit of a more universally applicable and less expensive marker of DLB and PDD pathology, provided they can be validated in future studies.

\section{Acknowledgements}

The authors thank the physicians who provided data on suspect cases to the German CJD Surveillance Unit and the Paracelsus-Elena Klinik in Kassel. We thank J.H. Growdon for critical reading of the manuscript and advice. This study was supported in part by a grant from the Bundesministerium für Gesundheit und soziale Sicherung and by the Bundesministerium für Forschung und Technik (M.O., S.P.). B.M., J.J.L. and M.G.S. are supported by a Michael J. Fox Foundation Biomarker grant; B.M. is also supported by a Dr. Werner Jackstaedt-Fellowship (Stifterverband für die Deutsche Wissenschaft). 
1 Noe E, Marder K, Bell KL, Jacobs DM, Manly JJ, Stern Y: Comparison of dementia with Lewy bodies to Alzheimer's disease and Parkinson's disease with dementia. Mov Disord 2004; 19:60-67.

2 McKeith IG, Galasko D, Kosaka K, et al: Consensus guidelines for the clinical and pathologic diagnosis of dementia with Lewy bodies (DLB): report of the consortium on DLB international workshop. Neurology 1996;47:1113-1124.

3 McKeith IG, Dickson DW, Lowe J, et al; Consortium on DLB: Diagnosis and management of dementia with Lewy bodies: third report of the DLB Consortium. Neurology 2005;65:1863-1872.

4 Marui W, Iseki E, Kato M, Akatsu H, Kosaka K: Pathological entity of dementia with Lewy bodies and its differentiation from Alzheimer's disease. Acta Neuropathol 2004;108: 121-128.

5 Emre M, Aarsland D, Albanese A, et al: Rivastigmine for dementia associated with Parkinson's disease. N Engl J Med 2004;351: 2509-2518.

6 Knopman DS, DeKosky ST, Cummings JL, et al: Practice parameter: diagnosis of dementia (an evidence-based review). Report of the Quality Standards Subcommittee of the American Academy of Neurology. Neurology 2001;56:1143-1153.

7 Frank RA, Galasko D, Hampel H, et al; National Institute on Aging Biological Markers Working Group: Biological markers for therapeutic trials in Alzheimer's disease. Proceedings of the biological markers working group; NIA initiative on neuroimaging in Alzheimer's disease. Neurobiol Aging 2003; 24:521-536.

8 Gomez-Tortosa E, Gonzalo I, Fanjul S, et al: Cerebrospinal fluid markers in dementia with Lewy bodies compared with Alzheimer disease. Arch Neurol 2003;60:1218-1222.

9 Mollenhauer B, Cepek L, Bibl M, et al: Tau protein, beta-amyloid $\operatorname{ar-42)}_{(10}$ and S-100B protein in cerebrospinal fluid of patients with dementia with Lewy bodies. Dement Geriatr Cogn Disord 2005;19:164-170.

10 Mollenhauer B, Bibl M, Wiltfang J, et al: Total tau protein, phosphorylated tau (181p) protein, beta-amyloid(1-42), and beta-amyloid(1-40) in cerebrospinal fluid of patients with dementia with Lewy bodies. Clin Chem Lab Med 2006;44:192-195.

11 Guillaume E, Zimmermann C, Burkhard PR, Hochstrasser DF, Sanchez JC: A potential cerebrospinal fluid and plasmatic marker for the diagnosis of Creutzfeldt-Jakob disease. Proteomics 2003;3:1495-1499.

12 Glatz JF, van der Vusse GJ, Simoons ML, Kragten JA, van Dieijen-Visser MP, Hermens WT: Fatty acid-binding protein and the early detection of acute myocardial infarction. Clin Chim Acta 1998;272:87-92.
13 Kleine AH, Glatz JFC, Van Nieuwenhoven A, Van der Vusse GJ: Release of fatty acidbinding protein into plasma after acute myocardial infarction in man. Mol Cell Biochem 1992;116:155-162.

14 Pelsers MM, Glatz JF: Detection of brain injury by fatty acid-binding proteins. Clin Chem Lab Med 2005;43:802-809.

15 Veerkamp JH, Zimmerman AW: Fatty acidbinding proteins of nervous tissue. J Mol Neurosci 2001;16:133-142.

16 Spillantini MG, Schmidt ML, Lee VM, Trojanowski JQ, Jakes R, Goedert M: Alphasynuclein in Lewy bodies. Nature 1997;388: 839-840.

17 Castagnet PI, Golovko MY, Barcelo-Coblijn GC, Nussbaum RL, Murphy EJ: Fatty acid incorporation is decreased in astrocytes cultured from alpha-synuclein gene-ablated mice. J Neurochem 2005;94:839-849.

18 Scherzer CR, Feany MB: Yeast genetics targets lipids in Parkinson's disease. Trends Genet 2004;20:273-277.

19 Sharon R, Bar-Joseph I, Mirick GE, Serhan CN, Selkoe DJ: Altered fatty acid composition of dopaminergic neurons expressing alpha-synuclein and human brains with alpha-synucleinopathies. J Biol Chem 2003; 278:49874-49881.

20 Sharon R, Bar-Joseph I, Frosch MP, Walsh DM, Hamilton JA, Selkoe DJ: The formation of highly soluble oligomers of alpha-synuclein is regulated by fatty acids and enhanced in Parkinson's disease. Neuron 2003;37:583595.

21 Sharon R, Goldberg MS, Bar-Josef I, Betensky RA, Shen J, Selkoe DJ: Alpha-synuclein occurs in lipid-rich high molecular weight complexes, binds fatty acids, and shows homology to the fatty acid-binding proteins. Proc Natl Acad Sci USA 2001;98:9110-9115.

22 Okada Y, Ito Y, Aida J, Yasuhara M, Ohkawa S, Hirokawa K: Lewy bodies in the sinoatrial nodal ganglion: clinicopathological studies. Pathol Int 2004;54:682-687.

23 Goldstein DS: Dysautonomia in Parkinson's disease: neurocardiological abnormalities. Lancet Neurol 2003;2:669-676.

24 Oide T, Tokuda T, Momose M, et al: Usefulness of $\left[{ }^{123} \mathrm{I}\right]$ metaiodobenzylguanidine ([ $\left.\left.{ }^{123} \mathrm{I}\right] \mathrm{MIBG}\right)$ myocardial scintigraphy in differentiating between Alzheimer's disease and dementia with Lewy bodies. Intern Med 2003;42:686-690.

25 Steinacker P, Mollenhauer B, Bibl M, et al: Heart fatty acid binding protein as a potential diagnostic marker for neurodegenerative diseases. Neurosci Lett 2004;370:36-39.

26 Hughes AJ, Daniel SE, Kilford L, Lees AJ: Accuracy of clinical diagnosis of idiopathic Parkinson's disease: a clinico-pathological study of 100 cases. J Neurol Neurosurg Psychiatry 1992;55:181-184.
27 Hoehn MM, Yahr MD: Parkinsonism: onset and mortality. Neurology 1967;17:427-442.

28 Fahn S, Elton RL; members of the UPDRS Development Committee: Unified Parkinson's Disease Rating Scale; in Fahn S, Marsden CD, Goldstein M, Caine DB (eds): Recent Developments in Parkinson's Disease. Florham Park, MacMillan Health Care Information, 1987, vol 2, pp 153-163.

29 Goetz CG: Treatment of advanced Parkinson's disease: an evidence-based analysis. Adv Neurol 2003;91:213-228.

30 Diener HC: Leitlinien für Diagnostik und Therapie in der Neurologie. Deutsche Neurologische Gesellschaft (DGN). Parkinsonsyndrome. Stuttgart, Thieme, 2003.

31 McKhann G, Drachman D, Folstein M, Katzman R, Price D, Stadlan EM: Clinical diagnosis of Alzheimer's disease: report of the NINCDS-ADRDA work group under the auspices of the Department of Health and Human Services task force Alzheimer's disease. Neurology 1984;34:939-944.

32 Sunderland T, Linker G, Mirza N, Putnam KT, Friedman DL, Kimmel LH, et al: Decreased $\beta$-amyloid and increased tau levels in cerebrospinal fluid of patients with $\mathrm{Alz}$ heimer disease. JAMA 2003;289:2094-2103.

33 Andreasen N, Minthon L, Clarberg A, Davidsson $\mathrm{P}$, Gottfries J, Vanmechelen E, et al: Sensitivity, specificity, and stability of CSFtau in $\mathrm{AD}$ in a community-based patient sample. Neurology 1999;53:1488-1494.

34 Hulstaert F, Blennow K, Ivanoiu A, et al: Improved discrimination of $\mathrm{AD}$-patients using $\beta$-amyloid(1-42) and tau levels in CSF. Neurology 1999;52:1555-1562.

35 Pelsers MM, Hermens WT, Glatz JF: Fatty acid-binding proteins as plasma markers of tissue injury. Clin Chim Acta 2005;352:1535.

36 Wodzig KW, Pelsers MM, van der Vusse GJ, Roos W, Glatz JF: One-step enzyme-linked immunosorbent assay (ELISA) for plasma fatty acid-binding protein. Ann Clin Biochem 1997;34:263-268.

37 Metz CE: Basic principles of ROC analysis. Semin Nucl Med 1978;8:283-298.

38 Braak H, Del Tredici K, Rüb U, de Vos RAI, Jansen Steur ENH, Braak E: Staging of brain pathology related to sporadic Parkinson's disease. Neurobiol Aging 2003;24:197-211.

39 Jellinger KA: Lewy body-related alpha-synucleinopathy in the aged human brain. J Neural Transm 2004;111:1219-1235.

40 Wiltfang J, Lewczuk P, Riederer P, et al: Consensus paper of the WFSBP Task Force on Biological Markers of Dementia: the role of CSF and blood analysis in the early and differential diagnosis of dementia. World J Biol Psychiatry 2005;6:69-84. 
41 Zabrocki P, Pellens K, Vanhelmont T, et al: Characterization of alpha-synuclein aggregation and synergistic toxicity with protein tau in yeast. FEBS J 2005;272:1386-1400.

42 Zimmermann-Ivol CG, Burkhard PR, Le Floch-Rohr J, Allard L, Hochstrasser DF, Sanchez JC: Fatty acid binding protein as a serum marker for the early diagnosis of stroke: a pilot study. Mol Cell Proteomics 2004;3:66-72.

43 Pelsers MM, Hanhoff T, Van der Voort D, et al: Brain- and heart-type fatty acid-binding proteins in the brain: tissue distribution and clinical utility. Clin Chem 2004;50:15681575 .
44 Wunderlich MT, Hanhoff T, Goertler M, Spener F, Glatz JF, Wallesch CW, Pelsers MM: Release of brain-type and heart-type fatty acid-binding proteins in serum after acute ischaemic stroke. J Neurol 2005;252: $718-724$.

45 Courbon F, Brefel-Courbon C, Thalamas C, et al: Cardiac MIBG scintigraphy is a sensitive tool for detecting cardiac sympathetic denervation in Parkinson's disease. Mov Disord 2003;18:890-897.

46 Tokuda T, Salem SA, Allsop D, et al: Decreased alpha-synuclein in cerebrospinal fluid of aged individuals and subjects with Parkinson's disease. Biochem Biophys Res Commun 2006;349:162-166.
47 Schlossmacher MG: Monitoring of $\alpha$-synuclein steady-state levels in vivo by ELISA. Mov Disord 2006;21(suppl 13):026.

48 Mollenhauer B, Trenkwalder C, Cullen V, et al: A platform for the quantification of alpha-synuclein in cerebrospinal fluid: Evidence for a potential biomarker for synucleinopathies. Neurodegenerative Dis 2007; 4(suppl 1):1-350(P463).

49 Takeuchi Y, Fukunaga K: Differential subcellular localization of two dopamine D2 receptor isoforms in transfected NG108-15 cells. J Neurochem 2003;85:1064-1074. 